\title{
Singerella n. gen., a separate genus for Clitocybe hydrogramma
}

\author{
Harri Harmaja \\ Botanical Museum, University of Helsinki, SF-00170 Helsinki, Finland
}

\begin{abstract}
Harmaja, H. 1974: Singerella n. gen., a separate genus for Clitocybe hydrogramma. Karstenia 14: 113-115.

Clitocybe (Fr.) Staude subg. Clitocybe sect. Bulluliferae (Sing.) Harmaja (Agaricales) is considered to deviate so much from the rest of the genus Clilocybe that a new genus, Singerella Harmaja, with Agaricus hydrogrammus Fr. as the type, is proposed for this single valid species of the section. The most important distinguishing character of the section Bulluliferae is the presence of peculiar vesicles in the hyphae of the epicutis (and mostly also in those of the cortex of the stipe), here called »intercalary dermatochrysocystidia», which are lacking in the other species of Clitocybe, and are probably also absent from the remainder of the Agaricales. They somewhat resemble the normal terminal chrysocystidia present in certain dark-spored genera. The second distinctive character is in the spores, some of which possess confluent bases. The odour of the species is almost unique in Clitocybe. Certain characters not reported before, such as responses to cotton blue of certain parts of the fruit body of the species in question, are given. The synonymy of $A$. hydrogrammus is given, two new synonyms of the species being included, resulting to the expansion of the area of this species to the southern hemisphere. One new combination becomes necessary: Singerella hydrogramma (Fr.) Harmaja.
\end{abstract}

The section Bulluliferae Sing. of Clitocybe (Fr.) Staude was erected by Singer (1943) because of the curious inflated elements of the hyphae of the epicutis and stipe cortex of Clitocybe hydrogramma (Fr.) Kumm., the type and only species of the section (this species was, however, given as $\gg$ C. kuehneri Sing., nom. nov.», which was not a validly published nomen novum as there was no reference to any original taxon description and because, in spite of that fact, a Latin diagnosis or a reference to such was lacking; moreover, it would have become a further taxonomic synonym of $C$. hydrogramma). Singer later reported these vesicles to be present also in the hyphae of the hymenophoral trama, but I have not observed them there in the specimens I have examined. In a recent study on Clitocybe (Harmaja 1969)
I accepted this section and included it in the type subgenus. Originally (1943) Singer also placed it in the type subgenus (subg. $\gg$ Eu-Clitocybe»), but later (SInger 1962) he changed his opinion and transferred the section to the subgenus Pseudolyophyllum. Pegler (1965) found that the Australian Agaricus clitocyboides Cooke \& Massee and Horak (1971) that the New Zealandic Leucopaxillus otagoënsis Stevenson bear these vesicles in their epicutis hyphae. They considered $A$. clitocyboides a valid species closely related to C. hydrogramma, and Horak (1971) regarded the Leucopaxillus species as a synonym of $A$. clitocyboides. I consider both as synonyms of $C$. hydrogramma for the moment since they differ from it only through the lack (or scarcity?) of the vesicles in the stipe cortex. 
At present I am continuing my attempts to make the genus Clitocybe more homogeneous taxonomically, and have already published two papers towards this end, transferring the C. gilva group (Harmaja 1969) and C. nebularis (HARMaja 1974) to the genus Lepista (Fr.) W.G. Smith. An evaluating of the characters of the section Bulluliferae, indicates that it too deserves to be transferred from $\mathrm{Cli}$ tocybe. As there is no genus to which it could be assigned, I propose a new genus to accommodate it, Singerella Harmaja, named in honour of Prof. Dr. Rolf Singer, Chicago, whose contributions to the taxonomy of the Agaricales, not least to Clitocybe, are of the utmost importance. The main diagnostic features of the new genus will be shortly discussed below. More information can be found in, e.g., KüHNER 1934 (Atlas: Pl. 64, as C . gallinacea) and Harmaja 1969: 26, 81-83.

The presence of the inflated elements, up to ca. $20 \mu \mathrm{m}$ in diameter, in the thin hyphae of the epicutis is a unique feature in Clitocybe, being peculiar to the section Bulluliferae. Horak (1968 and 1971) interprets these vesicles as chlamydospores, which, however, does not appear probable (HARMAJA 1969: 26). A better name would perhaps be »intercalary dermatochrysocystidia». When fresh these inflations contain an amorphous light-refractive central body, which normally disperses in exsiccates, where the contents are granulose throughout. According to my studies, the contents of the vesicles in dried basidiocarps are weakly cyanophilic (their walls being cyanophobic) and not conspicuously yellow when treated with $5 \% \mathrm{KOH}$. In the latter feature they deviate from both the chryso-vessels and the common type of chrysocystidia present in e.g. Pholiota, Stropharia and Nematoloma (from which they also differ in not having the normal terminal position). These vesicles are the most important character indicating the need for a separate genus for this species, as they seem to be unique, apparently being absent from the remainder of the order Agaricales.

A second feature deserving attention in the section Bulluliferae is the fact that some of the spores have confluent bases (perhaps the majority), the rest being acute-based and obtuse-based (Harmaja 1969). As a result, the hilar appendage/hilar region is thick, being ca. $0.5-0.9 \mu \mathrm{m}$ in diameter, and most of the spores are more or less lacrymoid in shape (the rest being \pm ellipsoid). All these spore characters are also typical of the type section of Clitocybe (syn. sect. Infundibuliformes; see Harmaja 1974), the confluent type of spore base being indeed restricted to these two sections. However, the section Bulluliferae is clearly distinguished from the section Clitocybe, not only by its epicutis, but also, which is very important, by the hygrophanity of its pileus, and lastly by the peculiar odour.

This striking, unpleasant smell of $C$. hydrogramma is the third character deserving attention, since it is almost unique in Clitocybe. Only a beech-forest race of $C$. strigosa Harmaja possesses a similar smell, although this species is quite different, belonging to the subgenus Pseudolyophyllum Sing. with dullcoloured species. As a result, when the epicutis is not examined, this race of $C$. strigosa is not infrequently confused with $C$. hydrogramma, which is likewise often common in beech forests.

Singerella Harmaja, n. gen. - Genus ex ordine Agaricales, e familia Tricholomataceae, habitu perfecte clitocyboideo. Pileus hygrophanus, infundibuliformis, colore haud obscuro. Lamellae pallidae, decurrentes. Sporae haud in tetradibus in preparatis e lamellis siccis factis, partim lacrymoideae, partim ellipsoideae, partim basi crassa confluente, partim acuta et obtusa; pariete tenui (ca. 0.15$0.20 \mu \mathrm{m}$ ), hyalino, laevi, non amyloideo nec dextrinoideo nec cyanophilo; intus eguttulatae, paulo cyanophilae; massa sporarum alba vel albida. Cortex pilei e strato uno; epicutis $e$ hyphis angustatis filamentosis, \pm parallelibus, passim inflatis, bullulis magnitudine ca. $12-30 \times 10-20 \mu \mathrm{m}$ praeditis. Structura corticis stipitis plerumque similis. Hyphae sine pigmentis membranae et incrustatis. Typus: Agaricus hydrogrammus Fr.

Singerella hydrogramma (Fr.) Harmaja, n. comb.

Agaricus hydrogrammus Fr., Systema mycologicum ... 1: 69. 1821. -- Clitocybe hydrogramma (Fr.) Kumm., Der Führer in die Pilzkunde: 122. 1871. - Omphalia hydrogramma (Fr.) Quél., Les champignons du Jura et des Vosges I: 238. 1872. Omphalina hydrogramma (Fr.) Quél., Enchiridion fungorum ...: 42. 1886. - Type: No original designation. No original specimens existing. A neotype has not yet been proposed.

Agaricus adirondackensis Peck, Rep. New York St. Cab. 23: 77. 1872. - Clitocybe adirondacken- 
sis (Peck) Sacc., Sylloge fungorum ... 5: 180. 1887. - Type: Holotype (NYS) studied.

Agaricus clitocyboides Cooke \& Massee, Grevillea 15: 98. 1887. - Clitocybe clitocyboides (Cooke \& Massee) Pegler, Australian Journ. Bot. 13: 328. 1965. - Type: Holotype (K) studied.

Clitocybe caespitosa Peck, Rep. New York St. Mus. 41: 61. 1888. - Type: Holotype (NYS) studied.

Omphalina jalapensis Murr., North American Flora 9: 349. 1916. - Type: See HarmaJA 1970. [Clitocybe kuehneri Sing., Ann. mycol. 41: 23. 1943. - Not validly published as lacking a Latin description and a reference to such (Int. Code
Bot. Nomencl., Art. 36). - »Type»: See HarmaJA 1969: 81 - 82.]

Leucopaxillus otagoënsis Stevenson, Kew Bull. 19: 19. 1964. - Type: Holotype (K) studied. ?Clitocybe hydrogramma (Fr.) Kumm. v. werneri Malençon, Bull. Soc. Mycol. France 58: 34. 1942. ?Clitocybe hydrogramma (Fr.) Kumm. v. gibboides Raithelhuber, Zeitschr. Pilzk. 34: 179. 1969.

Acknowledgements. - I wish to express my gratitude to the Director of the Royal Botanic Gardens and the Herbarium at Kew (K) and the Director of the New York State Museum (NYS) for providing type specimens for this study.

\section{REFERENCES}

Harmaja, H. 1969: The genus Clitocybe (Agaricales) in Fennoscandia. - Karstenia 10: $5-168$.

- 1970: Type studies on Agaricales described as Clitocybe and Omphalina. -- Karstenia 11: 35-40.

- 1974: A revision of the generic limit between Clitocybe and Lepista. - Karstenia 14: $82-92$.

HoraK, E. 1968: Synopsis generum Agaricalium (Die Gattungstypen der Agaricales) Beitr. Kryptogamenflora Schweiz 13: 1741.

- 1971, A contribution towards the revision of the Agaricales (Fungi) from New Zealand. - New Zealand Journ. Bot. 9: 403462.

KühneR, R. 1934: Clitocybe gallinacea (Scop.) Fr. Bull. Soc. Mycol. France 50: Atlas: Pl. 64.

Pegler, D. N. 1965: Studies on Australasian Agaricales. - Australian Journ. Bot. 13: 323356.

Singer, R. 1943: Das System der Agaricales. III. - Ann. Mycol. 41: 1-189.

- 1962: The Agaricales in modern taxonomy. 2nd ed. $-915+1-73$. Weinheim. 